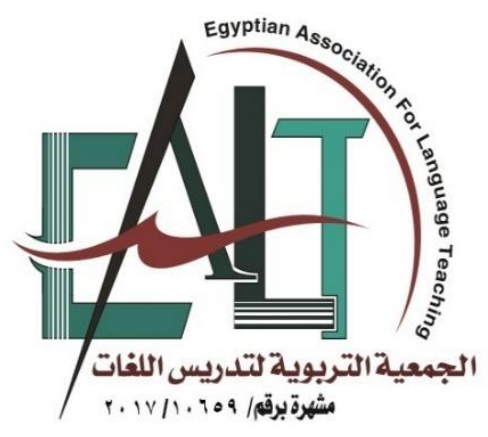

\title{
Research
}

\section{In Language Teaching}

A scientific Reviewed Journal of Teaching Languages

Chairman of the Association board Journal Editor- in- Chief

\section{Prof. Hanan Mohamed Hafez}

Professor of Curriculum and Instruction Faculty of Education - Ain Shams University

Secretary General of the Assembly Prof. Hassan Sayed Shehata

Professor of Curriculum and Instruction Vol. 3, January 2022 Issue № 18 



\section{Research in Language Teaching}

A scientific Reviewed Journal of Teaching Languages Published research expresses the researcher's point of view, which does not necessarily express the editors 'viewpoints or the policy of the journal

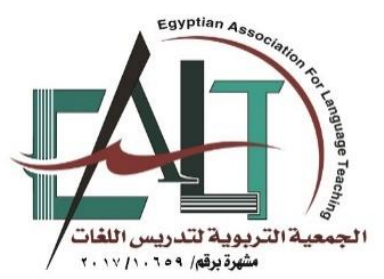

All correspondences should be addressed to the editor in chief "Ain Shams University - Faculty of Education - Department of Curriculum and Instruction - Roxi, Cairo"

E-mail Address :languagesearch@outlook.com Mobile: 01020675652

Electronic Site for the Educational Association for Teaching Languages. Website: http://languagesresearch.net Link for Egyptian Knowledge Bank: http://ssl.journals.ekb.eg/ International Standard Serial Number ISSN 2535-2148 Electronic International Standard Serial Number ISSN 2682-3519 Online 

Research in Language Teaching $\quad$ Vol.3, January 2022 Issue № 18

\section{Editorial board}

Journal Editor- in- Chief

Prof. Hanan Mohamed Hafez

Editorial secretary

Prof. Hassan Sayed Shehata

Editorial Board Members
Prof. Aza Abdel Razek
Prof. Badr Al Harbi
Prof. Mordi Zahrany
Prof. Wadeea Younes
Prof. Zenab El Nagar
Dr. Chérine Darwich
Dr. Dina Essawy
Dr. Amal Gaafar
Dr. Shaimaa Saïd

Editorial Secretariat

Mrs. Randa Ishak 
Research in Language Teaching $\quad$ Vol.3, January 2022 Issue № 18

\section{Scientific Committee}

Prof. Abed EI Mohaymen Kalefa

Prof. Ahmed El Afif

Prof. Ahmed Saif Eh Dine

Prof. Asmaa Ganem

Prof. Asmaa Mostafa

Prof. Aza Abdel Razek

Prof. Badr Al Harbi

Prof. Diaa El Nagar

Prof. Doaa Abdel Karim

Prof. Eid Abdel Wahed

Prof. Fahed Abdel Karim

Prof. Fayez Alshihri

Prof. Hanan Hafez

Prof. Hannaa Abdel Mawgoud

Prof. Haroun alsager

Prof. Hashem EI Samdani

Prof. Hassan Shehata

Prof. Hayssam Edan
Prof. Hazem Rashed

Prof. Hussein Taha Atta

Prof. Imane shalaby

Prof. Magdy Aly

Prof. Mahmoud Araby

Prof. Malak Halabi

Prof. Malika Kaheraoui

Prof. Maysoun Saad

Prof. Mohamed El shaway

Prof. Mordi Zahrany

Prof. Nabil Kassem

Prof. Nathalie Younes

Prof. Saad Aly EI Zayer

Prof. Sokry Megahed

Prof. Soraya EI Sayed

Prof. Wadeea Younes

Prof. Zenab EI Nagar

Prof. Zenab Helmy

The names are arranged in alphabetical order 


\section{Journal activities.............goals and scope}

The educational journal of language teaching seeks to achieve the following goals:

1. Publishing scientific journals in the field of languages and their teaching methods.

2. Developing the attitude towards languages considering that to be the main trend for the next century.

3. Providing help and educational services for associations and institutions interested in language teaching in general and improving language skills in particular.

4. Providing those who are responsible for curriculum planning for language teaching with the new trends in language teaching.

5. Emphasizing the role of language teaching in developing cognitive, affective and psychomotor levels.

6. Sharing experiences with universities, bodies, and institutions concerned with language teaching.

7. Holding conferences, seminars, and workshops on the most important issues and recent trends in language teaching. 
Research in Language Teaching Vol.3, January 2022 Issue № 18

8. Holding training courses in order to develop awareness of the importance of teaching languages and achieving the greatest degree of self-development for the individual.

9. Establishing a language teaching center, to train specialists to face problems and difficulties experienced by pupils and students when learning languages in different stages of education. 


\section{Publishing specifications}

The journal accepts publishing researches in the Arabic, English, French and German and other languages according to the following rules:

1. The research should be accompanied by two abstracts, one in the Arabic language and the other in the research language, provided that each abstract does not exceed (250 words).

2. The position and affiliation of the researcher should be referred to in the margin of the first page.

3. The researcher should submit two hard copies of the paper with attached (C.D), Word and PDF, in the following manner:

A- Setting the page is done by: leaving a space of 2.5 $\mathrm{cm}$ from the top of the page as well as from the bottom of it, and also leaving a space of $2.5 \mathrm{~cm}$ to the right and left of the page.

B- The writing font should be in Times New Roman for foreign texts.

C-The writing of the research body and references should be in font 14 , and 16 for the main headings, and14 for the side headings. 
$D$ - The space between the lines is $1.5 \mathrm{~cm}$, and the page does not exceed approximately 25 lines, and the research writes in a page size (Envelope B5 or ISO B5)

4. The research without appendices should not exceed 50 pages.

5. The research should be free from language errors.

6 . The research should take into account the usual general framework (introduction, theoretical framework, procedures, results, discussion, conclusions, references).

7. The references are written at the end of the research in alphabetical order, with a font size of 12 with the APA system.

8. The research is accompanied by an admission by the researcher that it was not previously published in any other journals and that it is not drawn from any study of any kind.

9. The research is sent to two referees in the specialty, provided that the researcher's data and identity are deleted.

10. The researcher is notified of the results of the review and referee, and in case of any modifications to the research, he/she must do them.

11. The researcher receives two copies of the research volume in which his research is published, in addition to five copies of his/ her own research only. 
12. For master's and doctoral research, the following should be taken into consideration:
A-The research should not exceed 20 pages + Arabic and English references + an Arabic and English abstract of the research.
B-Signing the research cover by the supervisors as well as signing the supervisor's report sheet.

13. Sending the research papers to:

\section{Prof. Hanan Mohamed Hafez Journal editor in chief}

On the following address: Faculty of Education, Department of Curriculum \& Instruction, Ain Shams University, Cairo, Roxy, Heliopolis

To contact the journal: Mobile: 01020675652

Email address/ languagesearch@outlook.com

The journal's website: http://languagesresearch.net

Egyptian knowledge bank link / http://ssl.journals.ekb.eg/ 


\section{The Ethics of Scientific Publishing in The Journal}

Due to the huge revolution in the techniques of collecting, preserving, retrieving and publishing information, the researcher has now a tremendous amount of information that can be relied upon in choosing his/ her hypotheses and ideas, and drawing his/ her judgments and findings. Hence the importance of having ethical criteria or regulations for academic and research work at the university and research centers has been stemmed from that. Scientific research requires a set of ethical values and principles that we summarize as follows:

- The research should be original.

- The research should consider and respect intellectual property.

- The research should be honest and accurate in documenting, analysing and publishing data and results, without lying, misleading or deceiving.

- Commitment to confidentiality of the data of each of the study participants.

- The research should be objective, unbiased, or manipulated when presenting the analysis of the data and its results. 


\section{The steps of the reviewing / refereeing process when receiving an article}

1. Researches are initially reviewed by the editorial board to decide whether it adheres to publication rules and whether it is eligible for refereeing.

2. Deleting all data of the researcher before sending the research to be refereed.

3. Sending the eligible research for refereeing by two accredited jury members with expertise and close specialization in the subject matter of the research, to evaluate it according to specific points (research evaluation form).

4. The journal is obliged to inform the researcher of the approval to publish the research without modification or according to certain modifications, based on what is mentioned in the referees' reports, or an apology for not publishing the research, with a statement of the reasons for the apology within fifteen days.

5. Informing the researcher about the date of publication of the research and the number of the volume where the research will be published.

6. For joint research, it is published with the consent of the parties participating in the research and not separately. 
Research in Language Teaching Vol.3, January 2022 Issue № 18

Index

\begin{tabular}{|c|c|c|}
\hline & The title of the research & $\begin{array}{c}\text { page } \\
\text { number }\end{array}$ \\
\hline 1 & Foreword & 16 \\
\hline 2 & $\begin{array}{l}\text { Entre le nombrilisme et le mimétisme dans Un amour } \\
\text { impossible de Christine Angot Écriture autofictionnelle } \\
\text { Dr. Manal Zahran El Bayoumi }\end{array}$ & 19 \\
\hline 3 & $\begin{array}{l}\text { L'aliénation dans "Le dernier colonel" de Jean Lods et " Il } \\
\text { était une fois un vieux couple heureux" de Mohamed Khaïr } \\
\text { Eddine. } \\
\text { Dr. Rihame Sabri Mohamed Abou Basha }\end{array}$ & 77 \\
\hline 4 & $\begin{array}{l}\text { L'effacement énonciatif, dans "La mort des Aztèques" de } \\
\text { Mouloud Mammeri. (objectivité ou subjectivité) } \\
\text { Dr. Dina Mohamed Salah Mahdie CHAFEI }\end{array}$ & 132 \\
\hline 5 & $\begin{array}{l}\text { Stylistique de l'instance narrative dans Eldorado de Laurent } \\
\text { GAUDE } \\
\text { Dr. Wael Fouad Naguib }\end{array}$ & 174 \\
\hline 6 & $\begin{array}{l}\text { La tragédie de Marie Stuart et Marie Antoinette } \\
\text { Chérine Ahmed Nasser Ismaill }\end{array}$ & 236 \\
\hline 7 & $\begin{array}{l}\text { La traduction arabe des expressions métaphoriques dans un } \\
\text { texte économique français Par les dictionnaires } \\
\text { électroniques Reverso et Almaany } \\
\text { Dr. Rabab Hamdi Kandil }\end{array}$ & 257 \\
\hline 8 & $\begin{array}{l}\text { Gender differences in perceiving FL culture teaching: The } \\
\text { case of Egyptian EFL pre-service teachers } \\
\text { Dr. Marghany Mahmoud Marghany }\end{array}$ & 338 \\
\hline 9 & $\begin{array}{l}\text { "To Mimic or not to Mimic: That is the Question": } \\
\text { Representation of the Concept of Mimicry in The } \\
\text { Inheritance of Loss and Under Copenhagen Sky: A } \\
\text { Comparative Study } \\
\text { Dr. Rasha F. M. Hamza }\end{array}$ & 380 \\
\hline 10 & $\begin{array}{l}\text { The Effect of a Proposed On-Job Task-Based Program on } \\
\text { Developing the English Language Fluency For Civil } \\
\text { Aviation Personnel } \\
\text { Hisham Mohamed Aly Desoky }\end{array}$ & 416 \\
\hline
\end{tabular}




\begin{tabular}{|c|c|c|}
\hline 11 & $\begin{array}{l}\text { Using Inquiry-Based Learning to Enhance Primary Stage } \\
\text { Students' } 21 \text { st Century EFL Literacy } \\
\text { Nevien Hussein Mohamed Shafeeq Gindya }\end{array}$ & 458 \\
\hline 12 & $\begin{array}{l}\text { EFL Teachers' Development through Professional Learning } \\
\text { Communities (A Case Study) } \\
\text { Shereen Abdelrazek Mohamed Kamel }\end{array}$ & 501 \\
\hline 13 & $\begin{array}{l}\text { Evaluationsstudie für die Lesefertigkeit bei DaF- } \\
\text { Studierenden an der Sprachenfakultät der MSA-Universität } \\
\text { im Lichte der kontrastiven Linguistik } \\
\text { Youssra Said Mohamed Elghonemy }\end{array}$ & 543 \\
\hline 14 & $\begin{array}{l}\text { Effizienz eines Modulprogramms zur Entwicklung des } \\
\text { Schreibens bei DaF-Studierenden an der Sprachenfakultät } \\
\text { der MSA-Universität aus der Sicht der angewandten } \\
\text { Linguistik } \\
\text { Youssra Said Mohamed Elghonemy }\end{array}$ & 585 \\
\hline 15 & 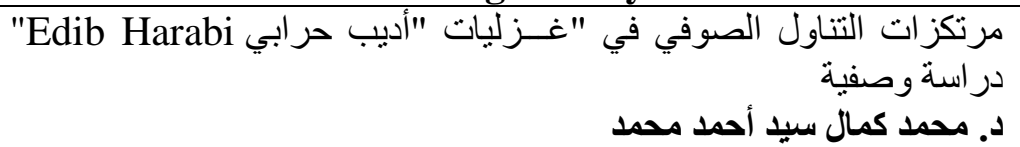 & 634 \\
\hline 16 & 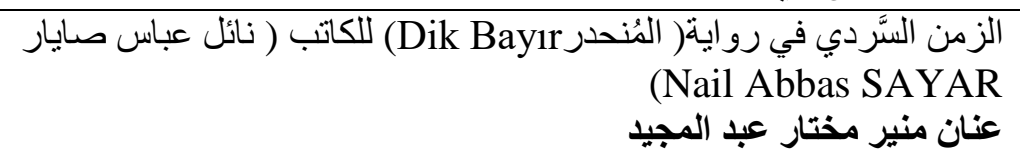 & 694 \\
\hline 17 & (فروز انعد الأصوات في القصة القصيرة (المدرسة الداخلية المجانية ) للأديبة التركية & 731 \\
\hline & د. إسلام محمد عبد الفتاح & \\
\hline 18 & 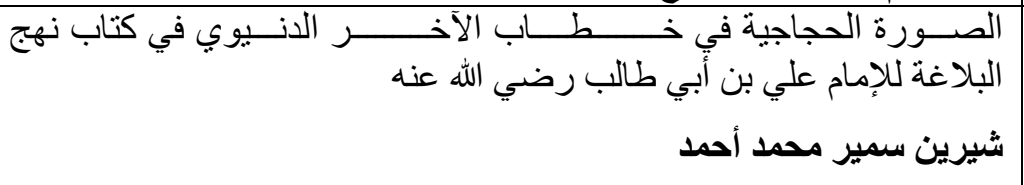 & 783 \\
\hline 19 & د. داهية الأسطورة في المذاهب النقدية الحديثة (در اسة نقدية مقارنة) & 817 \\
\hline 20 & التمية الحس شحاتهب اللغوي الفريضة الغائبة في تعليم العربية وتعلمها & 854 \\
\hline
\end{tabular}




\section{Foreword}

This is a monthly issued educational journal established in 2017 through the initiative of Dr. Hanan Hafez, its editor, as well as the participation of some teaching staff members specialized in language teaching and learning. The journal aims to publish research pertaining to teaching and learning languages and their teaching methods. It serves as a reference to teachers and novice researchers interested in this field. It is also considered as the first journal in Egypt in terms of publishing research concerned with language learning and teaching, seeking a high scientific level and cooperation with the institutions concerned. This uniqueness leads us to maintain the scientific quality of the published research, the novelty of topics, the soundness of scientific methodology, and the accuracy of language. The journal's review system is committed to transparency, promptness, and scientific accuracy. All thanks are dedicated to the researchers and teaching staff who enrich the journal with great efforts that seek its development.

\section{Préface}

La nouvelle revue intitulée (la revue égyptienne de la didactique des langues) est une revue pédagogique, à l'origine mensuelle, fondée en 2017 , à l'initiative de Dr. Hanan Hafez, avec une poignée du corps enseignant des diverses universités égyptiennes. Cette revue a pour finalité de diffuser en langues (française, anglaise, allemande et même arabe) l'actualité des travaux des recherches relatives à l'enseignement et à l'apprentissage des langues. C'est une revue de référence qui s'adresse aux enseignants, chercheurs et jeunes chercheurs impliqués dans ce domaine.

Ayant constaté que c'est la première revue présentée en Egypte susceptible de publier les recherches portant sur l'enseignement et 
l'apprentissage des langues. L'objet est de construire une revue égyptienne, de haut niveau scientifique travaillant en lien avec différentes institutions et équipe de recherche. Cette forme de distinction nous incite à accroître encore nos exigences en matière de qualité scientifique des recherches publiées, mais aussi dans leur évaluation, système que nous allons nous attacher à rendre transparent, rigoureux, rapide, respectueux du travail du corps enseignant et des évaluateurs, en nous l'espérons plus formatif. Nous tenons à remercier vivement tous les chercheurs et corps enseignant qui par leur aide et leur implication, ont permis l'élaboration de cette revue.

\section{Editorial}

Die pädagogische Zeitschrift für Sprachdidaktik ist eine monatliche, pädagogische Zeitschrift, die auf die Initiative von Prof. Dr. Hanan Hafez, der Redaktionsleiterin, und in Zusammenarbeit mit Fachkollegen im Bereich der Sprachlehr- und Lernforschung gegründet wurde.

Die Zeitschrift fasst sich als Forum für Forschungsbeiträge zum Lehren und Lernen der Sprachen und Ihre Unterrichtsmethoden auf. Als erste Zeitschrift in Ägypten, die sich der Sprachlehrforschung und dem Sprachunterricht widmet, will sie den interessierten Institutionen qualitativ bessere und verwertbare Forschungsergebnisse zur Verfügung stellen. Außerdem will sie als Referenz für Sprachlehrer und Forscher dienen. Beides kann nur durch innovative Ideen, die Einhaltung von Forschungsstandards und ein transparentes, faires und schnelles Begutachtungsverfahren erreicht werden. Allen Forschern und Dozenten, die zur Weiterentwicklung der Zeitschrift gebührt ein besonderer Dank. 